ISSN (print): 1698-6180. ISSN (online): 1886-7995

www.ucm.es/info/estratig/journal.htm

Journal of Iberian Geology 38 (2) 2012: 389-406

http://dx.doi.org/10.5209/rev_JIGE.2012.v38.n2.40465

\title{
The eclogite facies gneisses of the Cabo Ortegal Complex (NW Iberian Massif): Tectonothermal evolution and exhumation model
}

\author{
Los gneises eclogíticos del Complejo de Cabo Ortegal (NW del Macizo Ibérico): \\ Evolución tectonotermal y modelo de exhumación
}

\author{
R. Albert ${ }^{1}$, R. Arenas ${ }^{1}$, S. Sánchez-Martínez ${ }^{1}, A$. Gerdes $^{2,3}$ \\ ${ }^{1}$ Departamento de Petrología y Geoquímica and Instituto de Geociencias (UCM, CSIC), Universidad Complutense de \\ Madrid, 28040 Madrid, Spain \\ ${ }^{2}$ Institut für Geowissenschaften, Mineralogie, J.W. Goethe Universität, Frankfurt am Main, Germany. \\ ${ }^{3}$ Department of Earth Sciences, Stellenbosch University, Private Bag X1,Matieland 7602, South Africa. \\ *corresponding author: r.albert@geo.ucm.es
}

Received: 09/09/2012 / Accepted: 18/10/2012

\begin{abstract}
The tectonothermal evolution of the eclogite facies gneisses of the Cabo Ortegal Complex has been investigated using new field and petrologic studies. This gneissic unit is included in the high-pressure and high-temperature (HP-HT) upper units of the allochthonous complexes of NW Iberia, a Cambrian arc-derived peri-Gondwanan terrane emplaced above ophiolitic units considered to represent the Rheic Ocean suture. Two detailed cross-sections performed in excellent exposures on the Cantabrian coast allows a clear understanding of the lithological constitution and deformations affecting the unit. The eclogitic gneiss unit is constituted by metasedimentary gneisses with abundant mafic inclusions, felsic rocks and rare ultramafic inclusions. The felsic rocks range from centimetric leucosomes to metric bodies and most of them were generated during extensive partial melting affecting the unit. The first tectonic fabric detected in the unit is a rarely preserved S1 foliation developed during subduction (ca. 400-390 Ma; $22 \mathrm{kbar}$ ). A drastic and fast exhumation (ca. $390 \mathrm{Ma} ; 12-10 \mathrm{kbar}$ ) generated a regional mylonitic foliation which represents the most prominent structural feature in the HP-HT upper units. The consecutive generation of extensional detachments, recumbent folds and a basal thrust occurred during the change from continental-type subduction to the underthrusting of ophiolitic units. These consecutive structures are probably related and the consequence of a long and pronounced exhumation of the subducted complex. The tectonothermal evolution of the eclogite facies gneisses of the Cabo Ortegal Complex represents an illustrative example of the intricate history of these deeply subducted units, which are relatively frequent in the suture zone of the Variscan Belt. It is important to remark that the structural, metamorphic and geochronological patterns in the evolution of this gneissic unit follows almost perfectly the
\end{abstract}


predictions based in numerical experiments about the exhumation of ultra-high-P complexes. Consequently it represents a direct confirmation of these models.

Keywords: Eclogite facies gneisses, tectonothermal evolution, exhumation model, Variscan Belt, Cabo Ortegal Complex

\section{Resumen}

La evolución tectonotermal de los gneises eclogíticos del Complejo de Cabo Ortegal ha sido investigada con nuevos estudios de campo y petrológicos. Los gneises están incluidos en las unidades superiores de alta presión y alta temperatura (HP-HT) de los complejos alóctonos del NW de Iberia, consideradas parte de un terreno peri-Gondwánico de edad Cámbrica originado en un contexto de arco magmático. Este terreno se encuentra emplazado sobre diferentes unidades ofiolíticas que representan la sutura del Océano Rheico. Se han realizado dos secciones geológicas detalladas de afloramientos costeros que muestran las litologías constituyentes y las deformaciones que afectan a la formación gnéisica, que aparece constituida por paragneises con abundantes inclusiones máficas, rocas félsicas y escasas inclusiones de rocas ultramáficas. Las rocas félsicas varían desde leucosomas centimétricos hasta cuerpos métricos y la mayoría de ellas fueron generadas durante un proceso de fusión parcial generalizada. La primera fábrica tectónica detectada es una foliación relicta S1, muy raramente preservada, que se considera desarrollada durante un proceso de subducción (ca. 400-390 Ma; $22 \mathrm{kbar}$ ). La foliación regional milonítica, la estructura principal en las unidades de HP-HT, fue generada durante una drástica y rápida exhumación (ca. $390 \mathrm{Ma} ; 12-10 \mathrm{kbar}$ ). La generación consecutiva de despegues extensionales, pliegues recumbentes y de un gran cabalgamiento basal, tuvo lugar durante la transición desde la subducción de un margen continental hasta la imbricación de las unidades ofiolíticas. Estas estructuras sucesivas están probablemente relacionadas y son consecuencia de la pronunciada exhumación del complejo subducido. La evolución tectonotermal de los gneises en facies de las eclogitas del Complejo de Cabo Ortegal representa un ejemplo ilustrativo de la intrincada historia de estas unidades subducidas a gran profundidad, relativamente frecuentes en la zona de sutura de la Cadena Varisca. Es importante resaltar que las pautas estructurales, petrológicas y geocronológicas de la evolución de esta unidad gnéisica se ajustan con detalle a los modelos establecidos mediante experimentos numéricos para la exhumación de complejos de ultra-HP. Consecuentemente, la evolución descrita puede considerarse una confirmación directa de la verosimilitud de estos modelos.

Palabras clave: Gneises eclogíticos, evolución tectonotermal, modelo de exhumación, Cadena Varisca, Complejo de Cabo Ortegal

\section{Introduction}

The presence of terranes affected by high/ultra-high$\mathrm{P}$ metamorphism has been described in different collisional belts, where they represent the orogenic sections subducted to the highest depths and those affected by the oldest deformative and metamorphic events. Formation and exhumation of UHP rocks may occur during oceanic or thinned continental margin subduction either via continuous circulation in lithospheric scale wedges (Platt, 1986, 1993; Allemand and Lardeaux, 1997) or via return flow in low-viscosity overpressured subduction channels (Gerya et al., 2002; Gerya and Stöckhert, 2006; Yamato et al, 2008). However, some recent papers have stated that the development of ultra-high-P complexes is almost exclusively related to the subduction of thinned continental margins during early stages of continental collision, which necessarily implies the existence of a prograde continental margin facing a retro-continent (Chopin, 2003; Warren et al., 2008; Beaumont et al., 2009). Numerical modelling of exhumation of UHP units at the transition from oceanic subduction to continental collision indicates that the first order structural style of the orogenic domain is controlled by the penetration of an UHP buoyant plume (slice of subducting pro-continental margin) in the overlying lower pressure nappe pile. Therefore, to unravel the tectonothermal evolution of high/ultra-high-P complexes, an important tool is to investigate the tectonic and metamorphic processes generated during the first stages of the collision, those associated to deep subduction of crustal layers and the generation of thick orogenic wedges that frequently involve sections of lithospheric mantle.

Some high pressure and high temperature gneissic units including mafic rocks, with local ultra-high-pressure mineral assemblages, appear through the Variscan Belt outlining the main suture zone (Fig. 1; Gil Ibarguchi et al., 1990; Obrien and Vrana, 1995; Lardeaux et al., 2001; Massone, 2001; Arenas and Martínez Catalán, 2002). This type of units contains important information about the tectonothermal evolution of the Variscan or eo-Variscan accretionary complex, mainly because of the extreme metamorphic conditions attained and the superposition of deformational events that they register. The P-T evolution of these gneissic complexes is well described in some cases, but a detailed description of their internal structure and petrological constitution is generally lacking. Considering this and with the aim of a better understanding of the structure and evolution of the Variscan suture, we present a case study of a very good exposure of one of these units, the eclogite facies gneisses of the Cabo Ortegal Complex (Figs. 1 and 2), also previously 


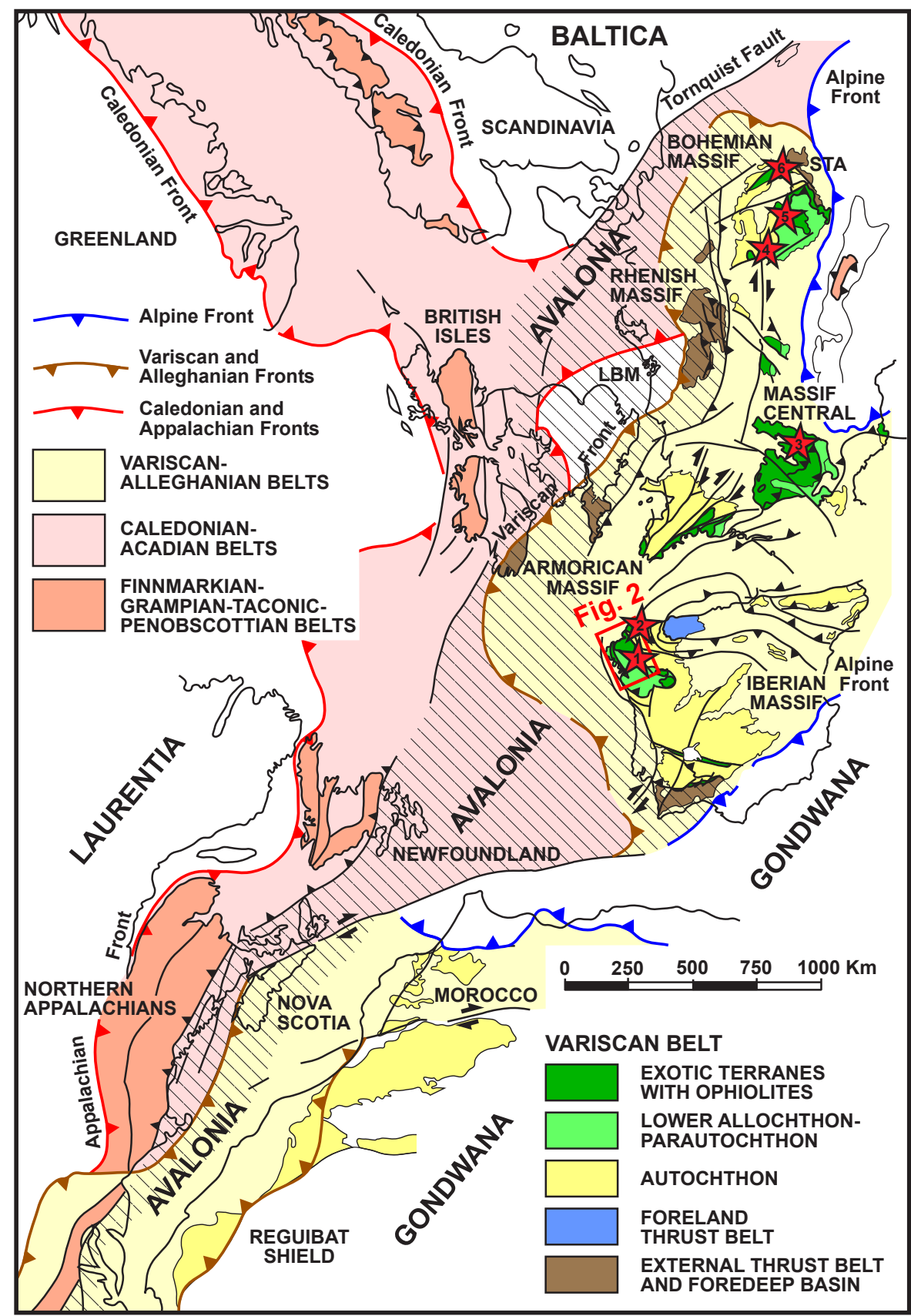

Fig. 1.- Sketch showing the distribution of the Paleozoic orogens in a reconstruction of the Baltica-Laurentia-Gondwana junction developed during the assembly of Pangaea. The distribution of the most important domains described in the Variscan Belt is also shown, together with the inferred position of the microcontinent Avalonia and the studied region in NW Iberia. Modified from Martínez Catalán et al. (2002). LBM: LondonBrabant Massif. STA: Silesian Terrane Assemblage. High-P and ultra-high-P units involved in the Variscan suture (red stars): 1) High-P and high-T unit of the Sobrado Antiform, Órdenes Complex (Arenas and Martínez Catalán, 2002); 2) Eclogite facies gneisses and related high-P and high-T rocks of the Cabo Ortegal Complex; 3) Coesite-bearing eclogite in the Monts du Lyonnais Unit, French Massif Central (Lardeaux et al., 2001); 4) High-P and high-T rocks in the Mariánské Lázně Complex, Bohemian Massif (Timmermann et al., 2004); 5) Eclogite facies gneisses bearing Cs + Dia in the Gneiss-Eclogite Unit, Saxonian Erzgebirge, Bohemian Massif (Massone, 2001; Massone, 2003; Massone et al., 2007); 6) High-P and high-T rocks in the Gory Sowie Block, Central Sudetes, Bohemian Massif (Kryza and Pin, 2002).

Fig. 1.- Esquema de la distribución de los orógenos Paleozoicos en una reconstrucción de la unión entre Baltica-Laurentia-Gondwana desarrollada durante el ensamblado de Pangea. También se muestra la distribución de los dominios más importantes descritos en la Cadena Varisca, junto con la posición inferida para el microcontinente Avalonia y la región estudiada en el NW de Iberia. Modificado de Martínez Catalán et al. (2002). LBM: Macizo de Londres-Brabant. STA: Asociación de terrenos de Silesia. Unidades de alta y ultra-alta-P involucradas en la sutura Varisca (estrellas rojas): 1) Unidad de alta-P y alta-T del Antiforme de Sobrado, Complejo de Órdenes (Arenas y Martínez Catalán, 2002); 2) Gneises en facies de eclogitas y rocas relacionadas de alta-P y alta-T del Complejo de Cabo Ortegal; 3) Eclogita con coesita de la Unidad Monts du Lyonnais, Macizo Central Francés (Lardeaux et al., 2001); 4) Rocas de alta-P y alta-T del Complejo de Mariánské Lázně, Macizo de Bohemia (Timmermann et al., 2004); 5) Gneises en facies de eclogitas con Cs + Dia de Erzgebirge, Sajonia, Macizo de Bohemia (Massone, 2001; Massone, 2003; Massone et al., 2007); 6) Rocas de alta-P y alta-T del Gory Sowie, Sudetes Centrales, Macizo de Bohemia (Kryza and Pin, 2002). 


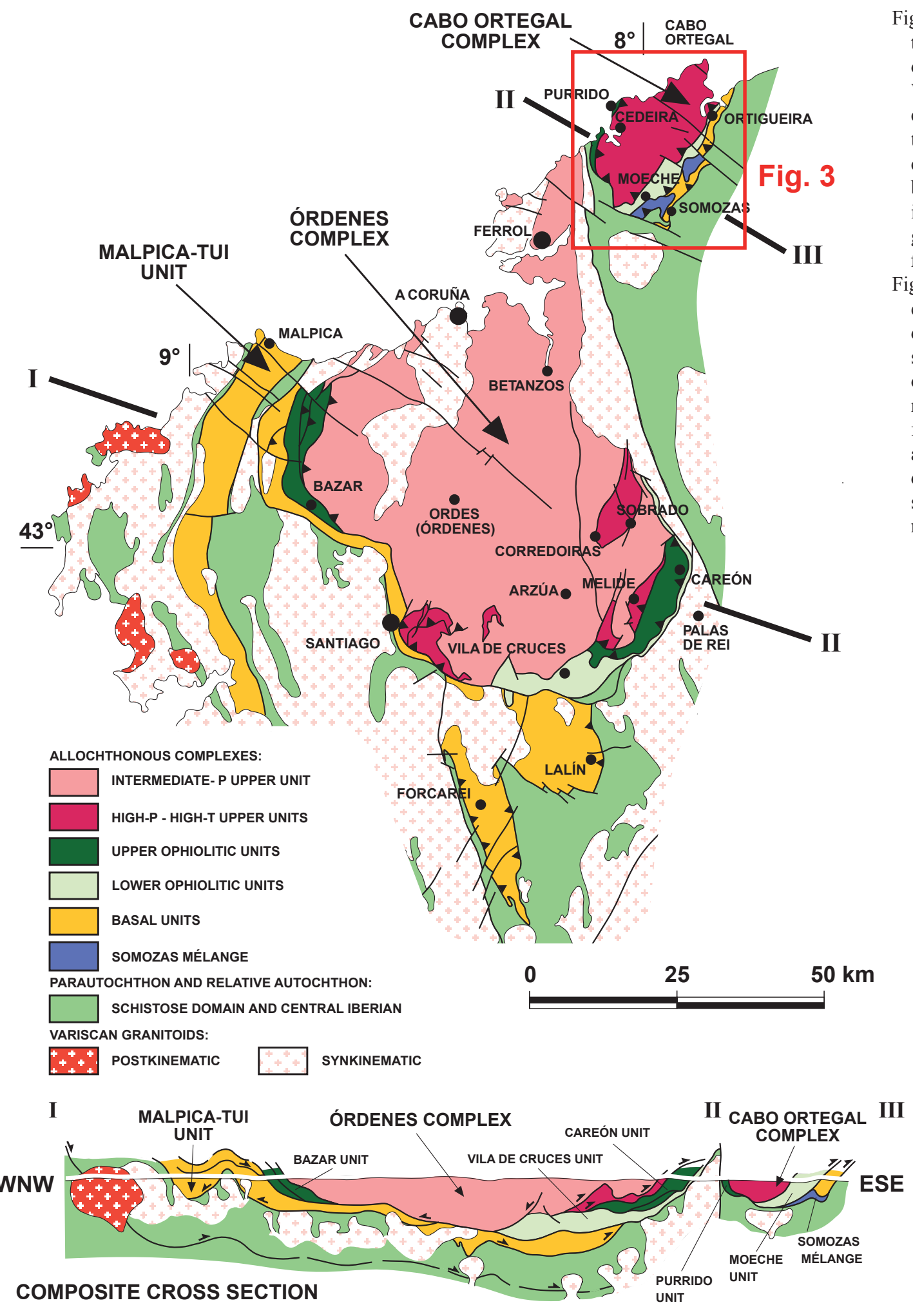

described as the Banded Gneiss Formation (Vogel, 1967). This gneissic formation appears as a highly sheared complex ensemble of metasedimentary rocks, eclogites and felsic rocks, together with their retrogressed products and abundant melts. The field relations of all of these rocks will be described using two detailed sections obtained in
Fig. 2.- Terrane distribution in the allochthonous complexes of NW Iberia (Galicia) and a WNW-ESE oriented general cross-section. The map shows the synformal structure of the complexes where a rootless branch of the Variscan suture is exposed. The location of the geological map presented in figure 3 is also shown.

Fig. 2.- Distribución de terrenos en los complejos alóctonos del NW de Iberia (Galicia) y sección geológica general con orientación WNW-ESE. El mapa muestra la estructura sinformal de los complejos donde aflora una rama desenraizada de la Sutura Varisca. También se indica la localización del mapa geológico de la figura 3 . 


\section{Geological context}

Five allochthonous complexes preserved at the NW of the Iberian Massif containing ophiolites and high pressure terranes are considered to be remnants of the Variscan suture (Figs. 1 and 2). This suture is rootless and problems exist for a clear correlation with the other suture zones described in the belt, although it is generally accepted that all of them correspond to a unique, more or less complex, oceanic domain, the Rheic Ocean (Simancas et al., 2005; Martínez Catalán et al., 2009). The allochthonous complexes show a late Variscan synformal structure and they are considered to be large klippens composed of several terranes, stacked in a huge and structurally intricated nappe pile (Fig. 2). These terranes recorded distinctive tectonothermal evolutions and are interpreted as dismembered fragments of a polycyclic Variscan and eo-Variscan accretionary complex. Each of the allochthonous terranes are subdivided in units which receive local names, but they can be correlated along the NW Iberian complexes (Cabo Ortegal, Órdenes, Bragança and Morais complexes, and the Malpica-Tui Unit), following similar basis to those used by Arenas et al. (1986). In a downwards structural order these terranes are constituted by: upper units, ophiolitic units and basal units, with a frontal serpentinitic mélange located at the base of the pile, the Somozas Mélange (Arenas et al., 2009). Below the allochthonous complexes, the Schistose Domain of Galicia-Trás-osMontes (or Parautochthon) shows a similar lithological constitution and tectonothermal evolution to those characteristic of the Iberian Autochthon (Central Iberian Zone of the Iberian Massif).

The upper units of the Cabo Ortegal Complex are subdivided in an uppermost member with intermediate pressure metamorphism (IP upper units) and a lower member affected by high pressure and high temperature metamorphism (HP-HT upper units). This terrane is considered a remnant of a Cambrian peri-Gondwanan magmatic arc (Fuenlabrada et al., 2010), rifted from the main continent (Gómez Barreiro et al., 2007) and affected by a polymetamorphic evolution developed during the magmatic arc stage and later during eo-Variscan times (Abati et al., 1999; Fernández Suárez et al., 2002). The ophiolitic units are generally subdivided in lower ophiolites and upper ophiolites, with Cambrian (ca. $500 \mathrm{Ma}$ ) and Devonian (ca. $395 \mathrm{Ma}$ ) ages respectively, and they are considered to represent the opening and closure of the Rheic Ocean (Díaz García et al., 1999; Arenas et al., 2007; Sánchez Martínez et al., 2007, 2011). The basal units represent a section of the most external Gondwanan margin, subducted at ca. 370 Ma during a collisional event consid- ered the first true Variscan deformation recorded in the belt (Arenas et al., 1995; Martínez Catalán et al., 1996; Abati et al., 2010; Díez Fernández et al., 2011).

The HP-HT units are constituted by paragneisses, mafic and ultramafic rocks, with some minor felsic bodies (Vogel, 1967; Girardeau et al., 1989; Gil Ibarguchi et al., 1990). The mafic rocks appear as different types of eclogites and Cpx-Grt granulites (pyrigarnites) and as their retrogressive products which include migmatitic amphibolitic gneisses, amphibolites and scarce greenschists. Gabbros occur in several stages of transformation, from rocks without any evidences of metamorphism to coronitic metagabbros, high-P granulites and amphibolites (Arenas and Martínez Catalán, 2002). In the upper units of the Cabo Ortegal Complex, both IP upper units and HP-HT units are represented. The IP upper units are only represented by amphibolite facies gneisses, the Cariño Gneisses. The HP-HT units include granulite facies gneisses (Chimparra Gneisses) and the deepest eclogite facies gneisses described in this paper (Banded Gneisses, Fig. 3). U-Pb zircon dating of the well preserved gabbros, eclogites and Cpx-Grt granulites indicates an age for the mafic protoliths in the range of 520-490 Ma, with a HP-HT metamorphic event ranging between 400-390 Ma (Santos Zalduegui et al., 1996; Ordóñez Casado et al., 2001; Fernández Suárez et al., 2007). The subsequent decompression of the HP-HT units was very fast, according to other $\mathrm{U}-\mathrm{Pb}$ ages obtained in leucosomes developed during migmatization of the mafic granulites which are almost indistinguishable from the high-P event and range between 397-390 Ma (Fernández Suárez et al., 2007). During their exhumation, the HP-HT units were affected by intense shearing that generated a pervasive mylonitic fabric with regional distribution, followed by the development of large recumbent folds and thrusts (Marcos et al., 1984; Ábalos et al., 2003, 2011; Puelles et al., 2009).

$\mathrm{P}-\mathrm{T}$ conditions of the eclogite facies metamorphism developed in the HP-HT units were estimated at $780-800{ }^{\circ} \mathrm{C}$ and $22 \mathrm{kbar}$, using classical thermobarometric techniques on the mineral assemblages from the main layer of eclogites (Fig. 3) in the Cabo Ortegal Complex (Mendia, 2000). This is a ca. $300 \mathrm{~m}$ thick band of massive eclogites located at the base of the eclogitic gneisses and it shows similar characteristics to other minor eclogites included in the eclogitic gneisses. The Cariño Gneisses, above the eclogitic gneisses, show metamorphic peak conditions calculated at $700 \pm 50{ }^{\circ} \mathrm{C}$ and $12 \pm 1,5$ kbar (Castiñeiras, 2005). Consequently it is clear that the Cariño Gneisses were not involved in the HP-HT event and that the contact with the eclogitic gneisses is an important extensional detachment. The metamorphic jump between both 

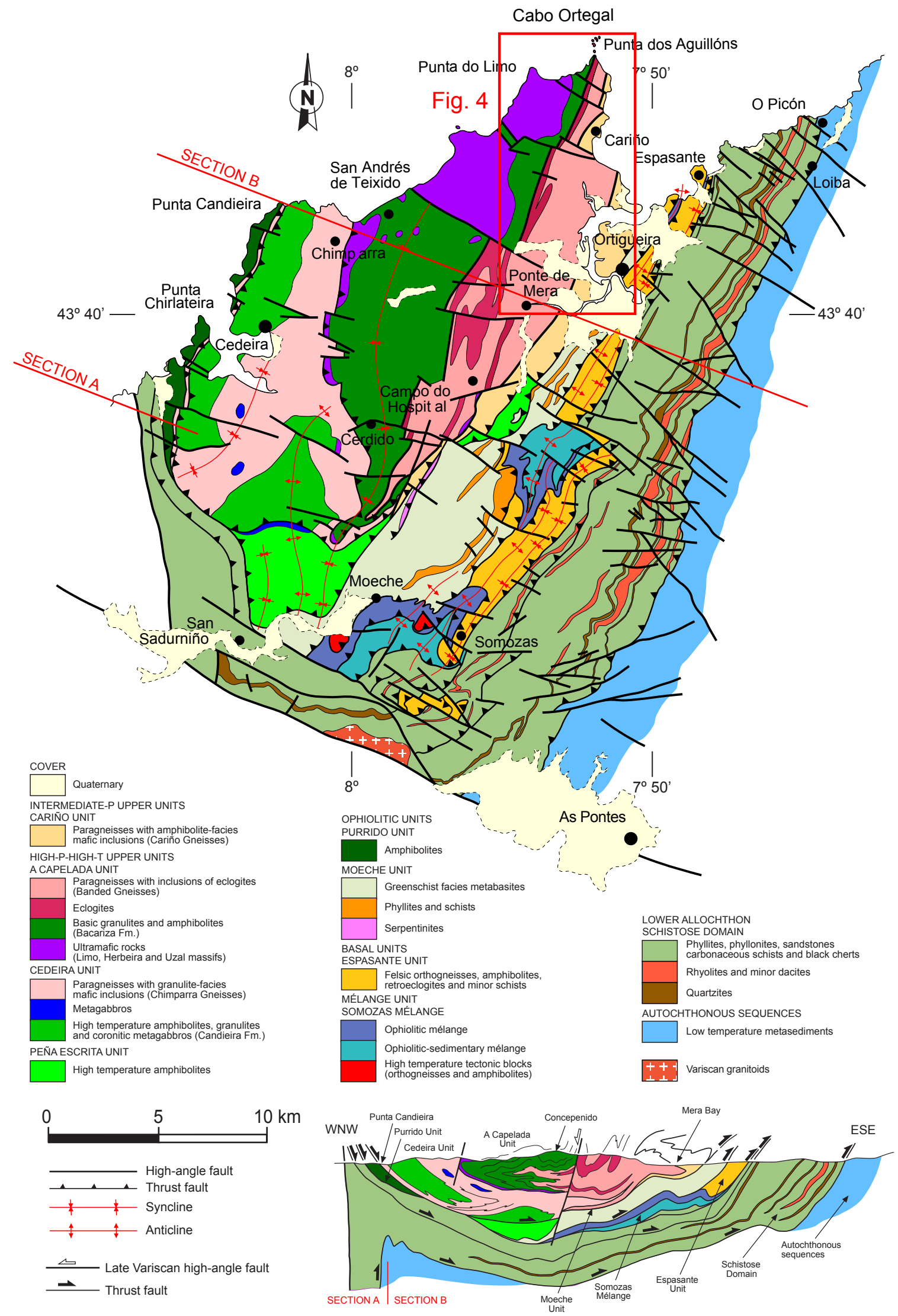

Fig. 3.- Geological map and cross-section of the Cabo Ortegal Complex. The location of the geological map presented in figure 4 is also shown. Modified from Vogel (1967), Marcos et al. (1984), Arenas et al. (1986, 2009).

Fig. 3.- Mapa geológico y sección transversal del Complejo de Cabo Ortegal. También se indica la localización del mapa geológico de la figura 4. Modificado de Vogel (1967), Marcos et al. (1984), Arenas et al. (1986, 2009). 


\section{GEOLOGICAL MAP AND CROSS-SECTIONS OF THE SURROUNDINGS OF CARIÑO (GALICIA, SPAIN)}

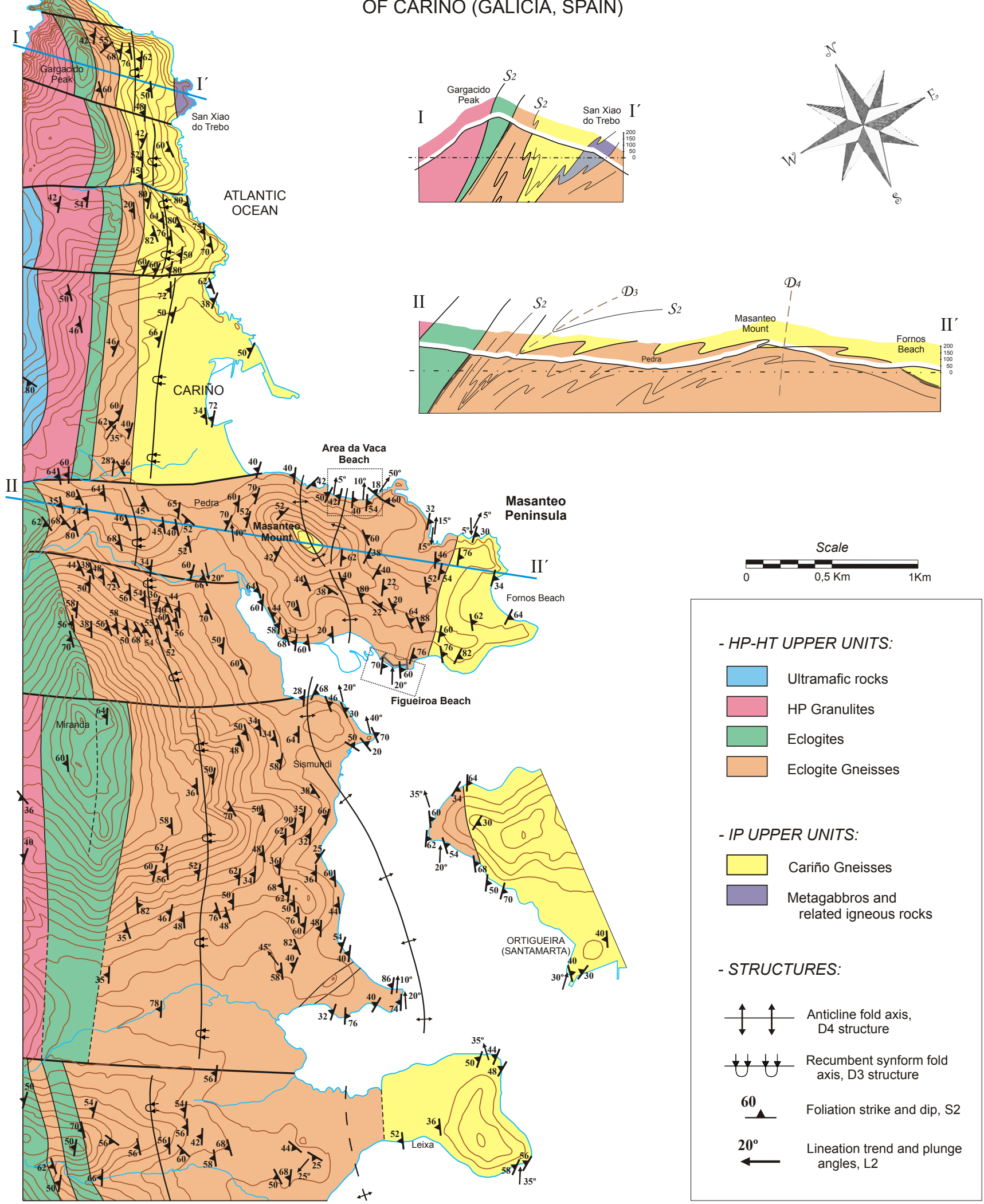

Fig. 4.- Geological map and cross-sections of the northern part of the eclogite facies gneisses. The location of Figueiroa and Area da Vaca sections are also shown.

Fig. 4.- Mapa geológico y secciones transversales de la parte septentrional de los gneises eclogíticos. También se indica la localización de las secciones geológicas de Figueiroa y Area da Vaca. 
gneiss formations can thence be calculated in the range of $10 \mathrm{kbar}$.

\section{The eclogite facies gneisses}

The eclogite gneisses is a ca. $20 \mathrm{~km}$ long and 500-700 $m$ thick unit (Figs. 3 and 4) mainly composed of metasedimentary rocks, eclogites, felsic rocks, abundant melts and their retrogressed products (Fig. 5). Some scarce inclusions of ultramafic rocks also appear in a unique locality. According to the coexistence of Omp + Grt (abbreviations after Kretz, 1983) in the mafic inclusions, this gneiss formation is the only one in the upper units of the Cabo Ortegal Complex that reached eclogite facies conditions. As the mafic inclusions are eclogites and retroeclogites we assume that the metasedimentary rocks were also eclogized, but they do not show any clear petrological evidence of an eclogite facies metamorphism as their mineral assemblages are not diagnostic from a petrographic point of view. This is probably due to the retrogradation processes that took place or because the mineral assemblage is only susceptible to reveal the HP conditions by thermodynamic modeling, which has not been performed. The metasedimentary rocks can be divided into metapelitic and metagreywackic types, and they always appear intensively migmatized and sheared displaying abundant quartzo-feldspathic leucosomes. The original sedimentary sequence was intruded by two main types of magmatic rocks. The first type, much more abundant than the second, was formed by diabasic dikes and gabbros now displayed as eclogites, retrogressed eclogites and rare coronitic metagabbros, while the second type is represented by thin inclusions of orthogneisses probably derived from granitic to tonalitic protoliths.

A unique exposure located in the Masanteo peninsula (Fig. 4) shows a thick mafic body of eclogites scarcely affected by post-peak shearing. The eclogites are intruded by abundant mesocratic melts with tonalitic compositions (Fig. 6f), showing outstanding features similar to those seen in a mingling of basic and felsic rocks. The mafic body does not show in its internal zone the common tight foliation that is generally observed along the formation. Instead this sector exhibits brecciated forms and rounded shapes in contact with the melt. Its mafic parts are well preserved eclogites, but the metamorphic conditions of the melts are not so clear because no distinctive mineral assemblages have been identified yet. However, we believe that the felsic rocks were probably derived from extensive partial melting affecting the metasedimentary gneisses during the first stages of decompression. These melts intruded and brecciated parts of the formation increasing heterogeneity, but their real participation in the gneiss formation can only be appreciated in the rare domains with moderate shearing. According to this data and interpretations, the participation in this formation of felsic material generated by decompressive partial melting can be very important, making difficult the distinction of the pre-metamorphic lithologies and compositions.

\subsection{Lithologies and mineral assemblages}

The most representative lithology in this formation is a gneiss bearing $\mathrm{Qtz}+\mathrm{Grt}+\mathrm{Pl}+\mathrm{Bt}+\mathrm{Ky}$ as primary minerals, which is considered a metasedimentary rock (Fig. 5b). According to their different compositions two distinctive gneissic types can be distinguished: one has relatively high alumina content and it is considered metapelitic; the other lacks Ky and the other alumina-rich minerals are scarce and therefore it is thought to be metagreywackic. In the field these gneisses define a banded formation variably migmatized but generally rich in centimetre to decimetre thick leucosomes which always appear sheared by the regional pervasive foliation. Within these gneisses there are two types of basic rocks: variably retrogressed eclogites with $\mathrm{Grt}+\mathrm{Cpx}+\mathrm{Hbl}+\mathrm{Pl}+\mathrm{Czo}+\mathrm{Rt}+\mathrm{Ilm}+\mathrm{Spn}$ (Fig. $5 \mathrm{f}$ and $5 \mathrm{~g}$ ); and what it is thought to be a prograde pre-eclogitic type, coronitic metagabbros composed of $\mathrm{Ol}+\mathrm{Grt}+\mathrm{Pl}+\mathrm{CzO}+\mathrm{Rt}+\mathrm{Ilm}+\mathrm{Spn}$ (Fig. 5h and 5i). The eclogitic inclusions are common in most sections of the gneiss formation, but the coronitic metagabbros are very rare. The eclogites and retrogressed eclogites are displayed as variably sized boudins, from decametres to centimetres, and in the case of the thicker inclusions they can contain an internal foliation different to the regional foliation that surrounds the boudins. In the best preserved eclogites it is possible to observe that this internal foliation was developed in eclogite facies conditions, because it is defined by the dimensional orientation of omphacite. Two types of orthogneisses can be distinguished, a granitic one with $\mathrm{Qtz}+\mathrm{Grt}+\mathrm{Pl}+\mathrm{Mc}+\mathrm{Bt}$ (Fig. 5d) and a tonalitic one with $\mathrm{Qtz}+\mathrm{Grt}+\mathrm{Pl}+\mathrm{Hbl}+\mathrm{Czo}$ (Fig. 5c). These orthogneisses do not define lenticular boudins as in the case of the mafic inclusions, by the contrary they appear as centimetre to metre thick leucocratic bands within the metasedimentary rocks, intensively sheared by the regional foliation.

\subsection{General structure}

\section{Detailed geological cross sections}

Five consecutive events were developed during the tectonothermal evolution of the eclogite facies gneisses. All of them generated representative structures that can be discussed using the good exposures of the coastal section. 

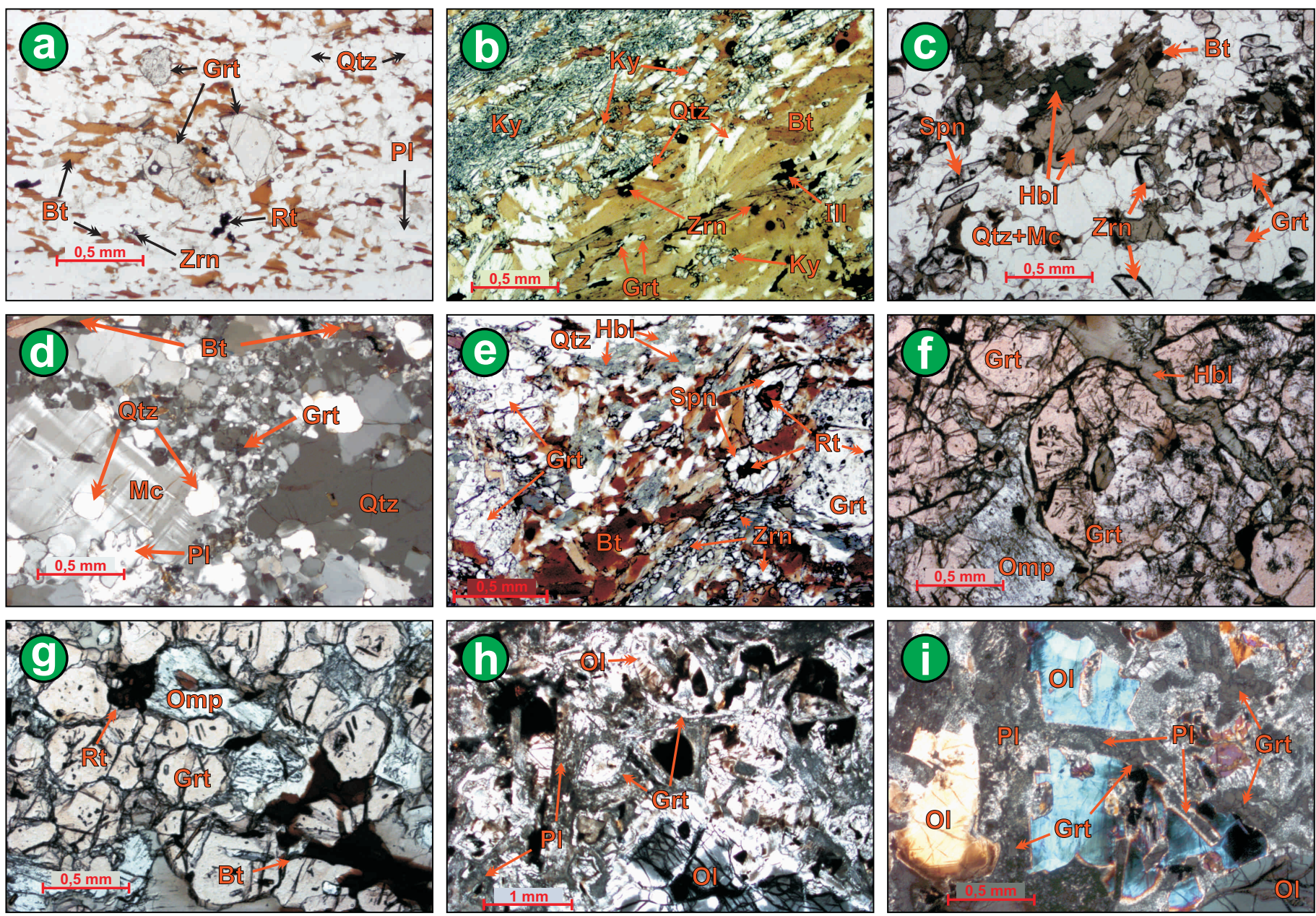

Fig. 5.- Photomicrographs of representative samples. a) Granolepidoblastic paragneiss (Qtz+Grt+Bt+Pl+Rt+Ilm+Spn); this sample lacks quartzofeldespathic leucosomes and was little affected by $\mathrm{D}_{2}$ retrogression, it corresponds to the paragneisses within the boudins shown in figures $6 \mathrm{c}$ and 6d.b) Banded paragneiss with abundant quartzo-feldespathic leucosomes and biotite rich domains (Qtz $+\mathrm{Grt}+\mathrm{Ky}+\mathrm{Bt}+\mathrm{Ms}+\mathrm{Pl}+\mathrm{Or}+\mathrm{Ilm}) . \mathrm{c}) \mathrm{Tonalitic}$ melt intruding eclogites in the North coast of the Masanteo Peninsula $(\mathrm{Qtz}+\mathrm{Grt}+\mathrm{Bt}+\mathrm{Ms}+\mathrm{Pl}+\mathrm{Hbl}+\mathrm{Czo}+\mathrm{Rt}+\mathrm{Ilm}+\mathrm{Spn})$; it corresponds to the felsic rocks in figure 6f. d) Granitic orthogneiss (Qtz $+\mathrm{Grt}+\mathrm{Bt}+\mathrm{Ms}+\mathrm{Pl}+\mathrm{Kfs}+\mathrm{Ilm})$. e) Amphibole bearing gneiss $(\mathrm{Qtz}+\mathrm{Grt}+\mathrm{Bt}+\mathrm{Pl}+\mathrm{Kfs}+\mathrm{Hbl}+\mathrm{Czo}+\mathrm{Ilm}+$ $\mathrm{Spn})$. f) Eclogite with Omp, Grt and secondary Hbl; inclusions in Grt are mainly Rt. g) Low retrogressed eclogite $(\mathrm{Qtz}+\mathrm{Grt}+\mathrm{Omp}+\mathrm{Hbl}+\mathrm{Bt}+\mathrm{Rt})$. h) Coronitic metagabbro with preserved ophitic texture; garnet coronas developed by reaction between $\mathrm{Ol}$ (preserved in the section) and $\mathrm{Pl}$ (replaced by $\mathrm{Ab}$ and $\mathrm{Ep}$ ). i) A detail in the previous coronitic metagabbro showing the garnet coronas between olivine and plagioclase.

Fig. 5.- Microfotografías de muestras representativas. a) Paragneis granolepidoblástico (Qtz+Grt+Bt+Pl+Rt+Ilm+Spn); esta muestra carece de leucosomas cuarzofeldespáticos y fue poco retrogradada durante $\mathrm{D}_{2}$, corresponde a los paragneises del interior de los boudins mostrados en las figuras 6c y 6d. b) Paragneis bandeado con abundantes leucosomas cuarzofeldespáticos y dominios ricos en biotita $(\mathrm{Qtz}+\mathrm{Grt}+\mathrm{Ky}+\mathrm{Bt}+\mathrm{Ms}+\mathrm{Pl}+\mathrm{Or}+\mathrm{Ilm})$. c) Fundidos tonalíticos intrusivos en eclogitas en la costa Norte de la Península de Masanteo (Qtz+Grt+Bt+Ms+Pl+Hbl+Czo+Rt+Ilm+Spn); corresponden a las rocas félsicas de la figura 6f. d) Ortogneises graníticos (Qtz+Grt+Bt+Ms+Pl+Kfs+Ilm). e) Gneis anfibólico (Qtz+Grt+Bt $+\mathrm{Pl}+\mathrm{Kfs}+\mathrm{Hbl}+\mathrm{Czo}+\mathrm{Ilm}+\mathrm{Spn}$ ). f) Eclogita con Omp, Grt y Hbl secundaria; las inclusiones en Grt son mayoritariamente Rt. g) Eclogita poco retrogradada (Qtz+Grt+Omp+Hbl+Bt+Rt). h) Metagabro coronítico con textura ofítica preservada; las coronas de granate se desarrollaron por reacción entre $\mathrm{Ol}$ (preservado) y Pl (reemplazada por Ab y Ep). i) Detalle del metagabro coronítico de la figura $6 \mathrm{~h}$ mostrando las coronas de granate entre el olivino y la plagioclasa.

Two of these exposures have been studied in detail and two geological cross sections have been performed. The geological section of Figueiroa beach (Fig. 7) is located in the South coast of the Masanteo Peninsula (Fig. 4). It is a 210 metre long outcrop representation, which is very close to the eastern boundary of the eclogitic gneisses. This section shows a quasi-homoclinal sequence that dips to the East with an average angle of 50 to $80^{\circ}$ trending $\mathrm{N}$ to $\mathrm{N} 20^{\circ} \mathrm{E}$. It includes almost all types of lithologies, where orthogneisses are scarce and eclogites are abundant. The most obvious structural feature is a generalized $\mathrm{S}_{2}$ mylonitic foliation developed during a $\mathrm{D}_{2}$ deformative event with regional distribution. This $\mathrm{S}_{2}$ foliation surrounds the larger mafic boudins and appears folded by 

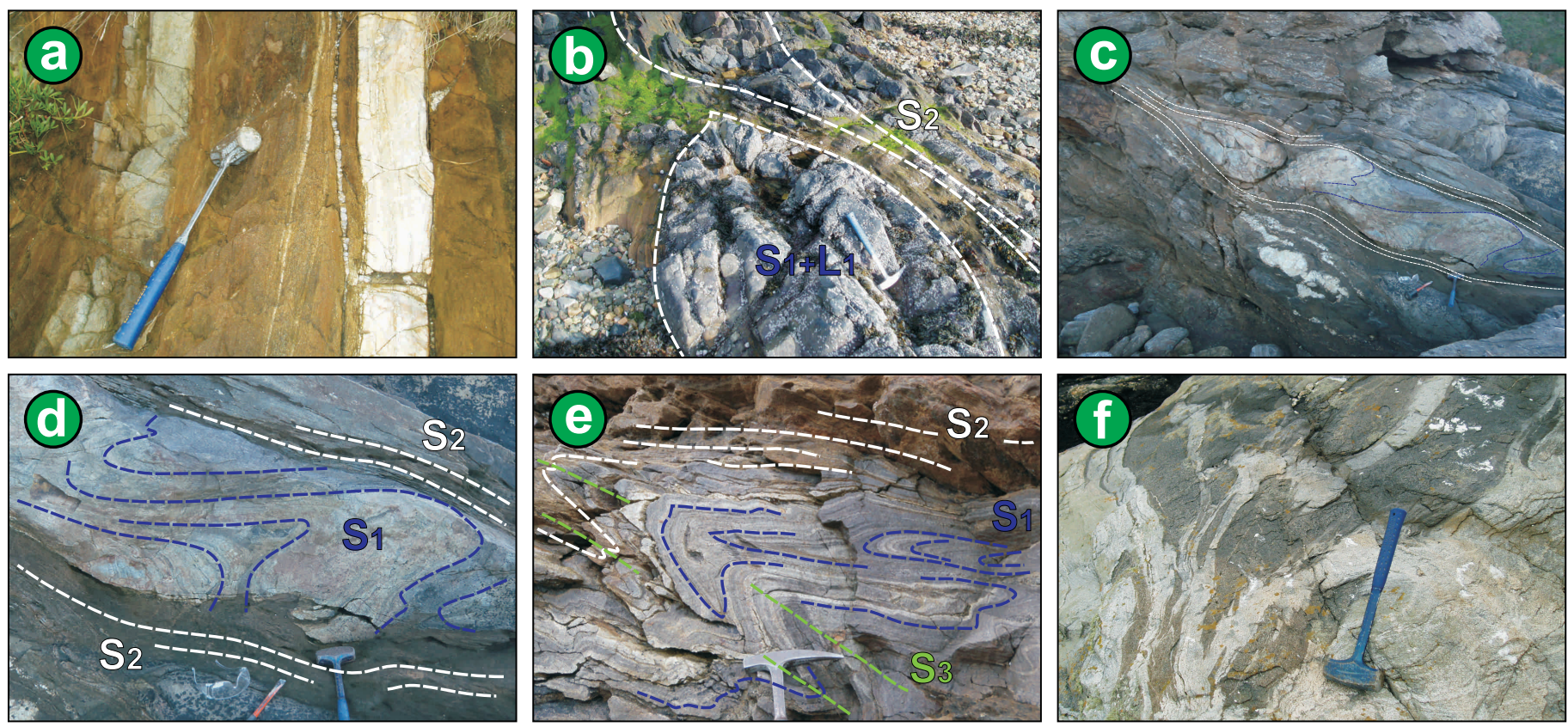

Fig. 6.- Photographs of some representative outcrops of the eclogite facies gneisses in the Masanteo Peninsula (Fig. 4). a) Eclogite (mafic left layer) and orthogneiss (felsic right layer) within paragneisses. b) Eclogite boudin with preserved internal fabric surrounded by the metasedimentary gneisses. c) Slightly sheared gneissic boudin surrounded by the regional $\mathrm{S}_{2}$ foliation; the boudin preserves an internal fabric interpreted as the relict $\mathrm{S}_{1}$ foliation, and lacks quartzo-feldespathic leucosomes. d) Enlarged aspect of the previous low deformed gneissic lens; it is surrounded by other highly sheared migmatitic gneisses, the common gneiss type in the eclogite facies gneisses. e) Slightly sheared gneissic lens showing a relict $\mathrm{S}_{1}$ foliation tightly folded during the regional $\mathrm{D}_{2}$ event, which produces the $\mathrm{S}_{2}$ foliation outlining the outcrop; recumbent $\mathrm{D}_{3}$ folds, without associated axial planar foliation, developed later. f) Large eclogitic outcrop intruded by tonalitic melts and later affected by tight recumbent folds.

Fig. 6.- Fotografías de algunos afloramientos representativos de los gneises eclogíticos en la Península de Masanteo (Fig. 4). a) Eclogita (capa máfica de la izquierda) y ortogneis (capa félsica) entre paragneises. b) Boudin de eclogita con fábrica interna preservada envuelto por los gneises metasedimentarios. c) Boudin gnéisico poco cizallado envuelto por la foliación regional $\mathrm{S}_{2}$; el boudin preserva una fábrica interna interpretada como la foliación $\mathrm{S}_{1}$ relicta, y carece de leucosomas cuarzofeldespáticos. d) Aspecto ampliado del boudin gnéisico anterior con escasa deformación; está envuelto por otros gneises migmatíticos intensamente cizallados, que representan el tipo de gneises más común. e) Boudin gnéisico poco cizallado que contiene una foliación relicta $\mathrm{S}_{1}$ fuertemente plegada durante el evento regional $\mathrm{D}_{2}$, al que también se asocia la foliación regional $\mathrm{S}_{2}$ que envuelve al afloramiento; los pliegues recumbentes $\mathrm{D}_{3}$, sin desarrollo de foliación de plano axial, se generaron posteriormente. f) Gran afloramiento de eclogitas intruidas por líquidos de composición tonalítica y con desarrollo posterior de pliegues recumbentes apretados.

upright folds developed during a $\mathrm{D}_{4}$ deformation (previous large $\mathrm{D}_{3}$ recumbent folds are not obvious in these sections. They can be observed in a larger scale in figures 3 and 4). The geological section of Area da Vaca beach is 490 metres long (Fig. 8) and it is situated at the north coast of the Masanteo Peninsula (Fig. 4). In this section the eclogites are not abundant whereas the orthogneisses are very numerous, especially in the central part where the eclogites are missing. At the beginning and at the end of this section two large bodies of eclogites appear. The original contacts with the gneisses were important shear zones, but now they appear overprinted by brittle faults. The whole section defines a wide and open $\mathrm{D}_{4}$ major antiform, and also shows a folded $\mathrm{S}_{2}$ foliation that actually surrounds the large mafic bodies. Some of the felsic rocks show syntectonic relations with $\mathrm{S}_{2}$ suggesting that they were generated during partial melting coeval with this deformative event. Some of the felsic rocks in this section also define $\mathrm{D}_{2}$ folds, and in few cases an $\mathrm{S}_{2}$ axial plane foliation can be observed. Other observations supporting this syn-tectonic $\mathrm{D}_{2}$ nature of some felsic rocks are there post-eclogitic and intrusive nature (Fig. 6f) observed in few outcrops at the north coast of the Masanteo Peninsula (Fig. 4) and that it seems that there development took place synchronously with $\mathrm{S}_{2}$ due to the observation of elongated mineral aggregates with a highly ductile aspect, which is compatible with a syn-kinematic crystallization of a melt. In the Area da Vaca section and in few cases in the Figueiroa section, the larger eclogitic boudins include an internal foliation previous to the regional one. Considering that in the best preserved boudins this foliation is defined by the minerals forming the eclogitic mineral assemblage, this foliation is considered an $\mathrm{S}_{1}$ fabric developed during the eclogitic subductive event $\left(\mathrm{D}_{1}\right)$.

\section{Structure of the eclogite facies gneisses}

Taking into account the lithological and structural data obtained in these two sections, and also the additional in- 
formation about the largest structures in the region that can be deduced from the geological maps and the general cross sections (Figs. 3 and 4), the deformative events affecting the eclogitic gneisses can be summarized as follows.

Evidence for an eclogite facies metamorphism and associated fabric $\left(D_{1}-S_{1}\right)$ can be obtained from some mafic inclusions but only in few cases in the metasedimentary gneisses. During the eclogitic metamorphism a foliation $\left(\mathrm{S}_{1}\right)$ and a lineation $\left(\mathrm{L}_{1}\right)$ that show a top-to-north sense of movement (Ábalos et al., 2003, 2011) were developed in the mafic rocks, being generally difficult to observe. The observation of $\mathrm{D}_{1}$ features is even more elusive in the metasedimentary rocks, because the next deformational event $\left(D_{2}\right)$ almost totally erased the previous structures and mineral assemblages by intense shearing and retrogradation processes. Only in few outcrops of gneisses in the Masanteo Peninsula, some metric boudins of metasedimentary rocks surrounded by the $\mathrm{S}_{2}$ foliation but showing little shearing associated to $\mathrm{D}_{2}$ and preserving $\mathrm{D}_{1}$ features have been observed (Fig 6 $\mathrm{d}$ and 6e). In this case the distance between $S_{1}$ foliation planes is wider $(1-2 \mathrm{~cm})$ than $S_{2}$ planes $(0.1-1 \mathrm{~cm})$, and the quartzo-feldespathic domains are less differentiated (i.e. quartzo-feldespathic domains due to metamorphic differentiation are less felsic than those from metasedimentary rocks were only $\mathrm{D}_{2}$ is recognised). It is not possible to observe any mineralogical differences between these gneisses and the same gneisses affected by $\mathrm{D}_{2}$ shearing, but microscopic textural differences do exist. In the gneisses preserving $\mathrm{D}_{1}$ features there is no secondary mineral growth, no migmatization is found (i.e. leucosomes due to anatexis are not found), and the lepidoblastic minerals such as Bt are not highly concentrated in the foliation planes. The existence of previous Cambrian deformations in the upper units has been demonstrated by different authors using U-Pb geochronological data (Fernández Suárez et al., 2002; Abati et al., 2007; Díaz García et al., 2010). These deformations were developed during the generation of the protoliths in a Cambrian peri-Gondwanan magmatic arc. However, there is no evidence of any pre- $\mathrm{D}_{1}\left(\mathrm{D}_{0}\right)$ fabric or mineral assemblage in the gneiss formation, in accordance with the extreme metamorphic conditions developed during the eclogite facies metamorphism, except of some igneous minerals preserved in scarce coronitic metagabbros (Fig. 5h and 5i).

The characteristic banding in this formation is a result of the extreme deformation developed during $\mathrm{D}_{2}$ event. All along this stage the formation experienced mylonitic decompressive shearing and migmatization, developing an $\mathrm{S}_{2}$ foliation that presently shows a regional distribution. $\mathrm{S}_{2}$ has an approximately $\mathrm{N} 20^{\circ} \mathrm{E}$ strike, and dips to the West or to the East (Fig. 4). Associated to $\mathrm{S}_{2}$ foliation there is an $\mathrm{L}_{2}$ lineation with top-to-north sense of movement. This lineation trends $\mathrm{N} 10^{\circ} \mathrm{E}-\mathrm{N} 30^{\circ} \mathrm{E}$ and has a plunge ranging $5^{\circ}-30^{\circ}$, generally due NE. $\mathrm{S}_{2}$ is a pervasive mylonitic fabric that wraps around the larger eclogite bodies and also generates zones of tectonic mix by extreme shearing and mixing of retrograded mafic rocks, gneisses and melts (m.175, Fig 7). Other than small tight folding, almost isoclinal, there is local formation of sheath folds, both most probably formed by $\mathrm{D}_{2}$. The generalized migmatization concentrates the quartzo-feldespathic aggregates in large lenses (various centimetres) and in very small pods (up to $1-2 \mathrm{~cm}$ ), which gives an augen aspect to some parts of these gneisses.

The regional distribution of the gneiss formation is controlled by large recumbent folds with an East vergence $\left(\mathrm{D}_{3}\right)$, always folding $\mathrm{S}_{2}$. The largest of these folds is a kilometric scale recumbent synform which is the most prominent feature in the general structure of the upper units in the Cabo Ortegal Complex (Fig. 3 and sections I-I' and II-II' of Fig. 4). This synform was early mapped by Vogel (1967), but its real significance and detailed geometry was presented by Marcos et al. (1984). Its axial plane is sub-horizontal and strikes in a N-S direction at regional scale (Fig. 3), although in the eastern part of the complex it dips to the West (Fig. 4). This large recumbent fold rarely developed an axial planar foliation $\left(\mathrm{S}_{3}\right)$ that has been observed close to the hinge zone only in the Cariño Gneisses. Another related recumbent fold can be observed in the eastern limit of the upper units, where the Cariño Gneisses appear below the eclogitic gneisses dipping to the West and directly in contact with the Moeche Ophiolite (Fig. 3). These relations necessarily imply that a tight recumbent antiform exists under the large synform. Many evidences of recumbent folding can be seen in the hinge zone of this antiform, near the contact with the Moeche Ophiolite, especially in the Leixa area (Fig. 4). The age of the recumbent folds is not accurately known, but it is certainly younger than the emplacement of the IP upper units over the HP-HT units, because the limit between them is also folded by the large synform (Figs. 3 and 4).

The upper units of the Cabo Ortegal Complex are thrust over the ophiolites represented by the Purrido and Moeche units (Fig. 3). The recumbent antiform of the eastern limit rests directly over the thrust. Evidence of important shearing can be seen in the contact zone. The deformation occurred in greenschist facies conditions and a new mylonitic fabric appears in the Cariño Gneisses and especially in the greenschists of the Moeche Ophiolite. The geometry of the recumbent folds and the thrust seem to indicate that the generation of both types of structures 


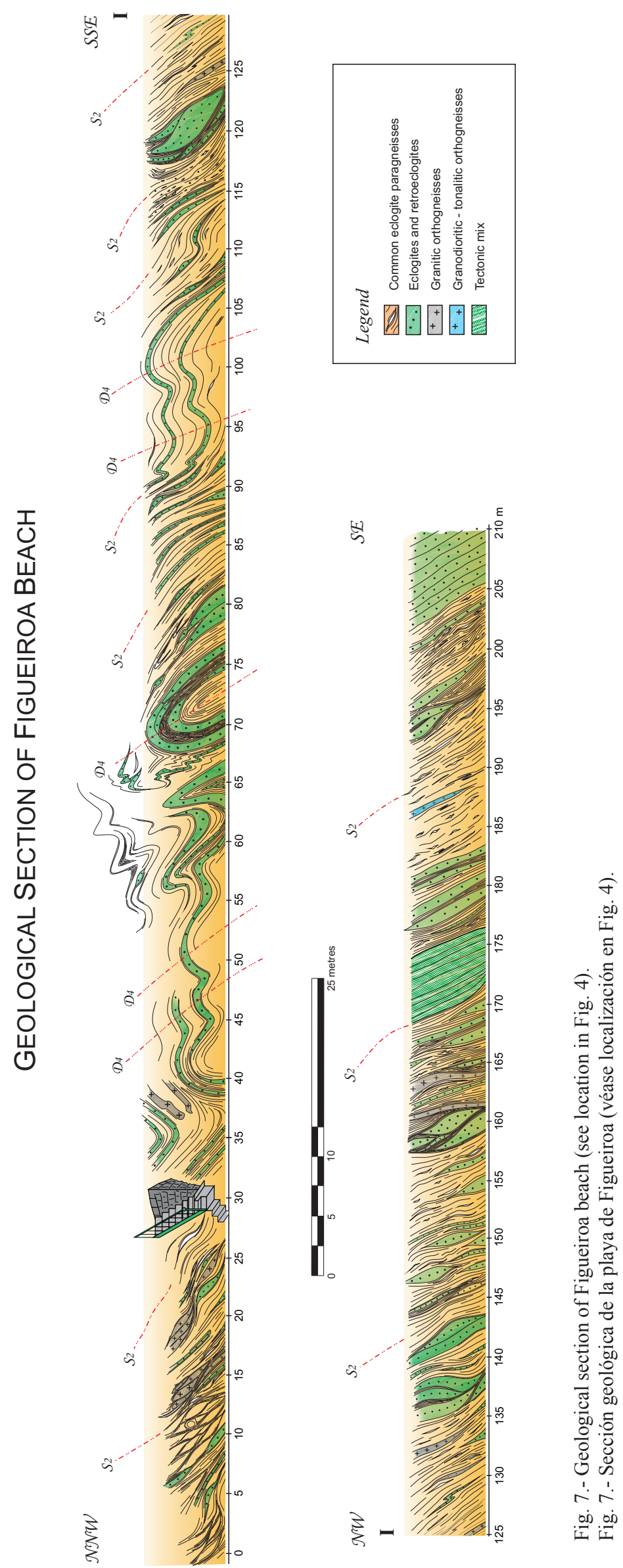



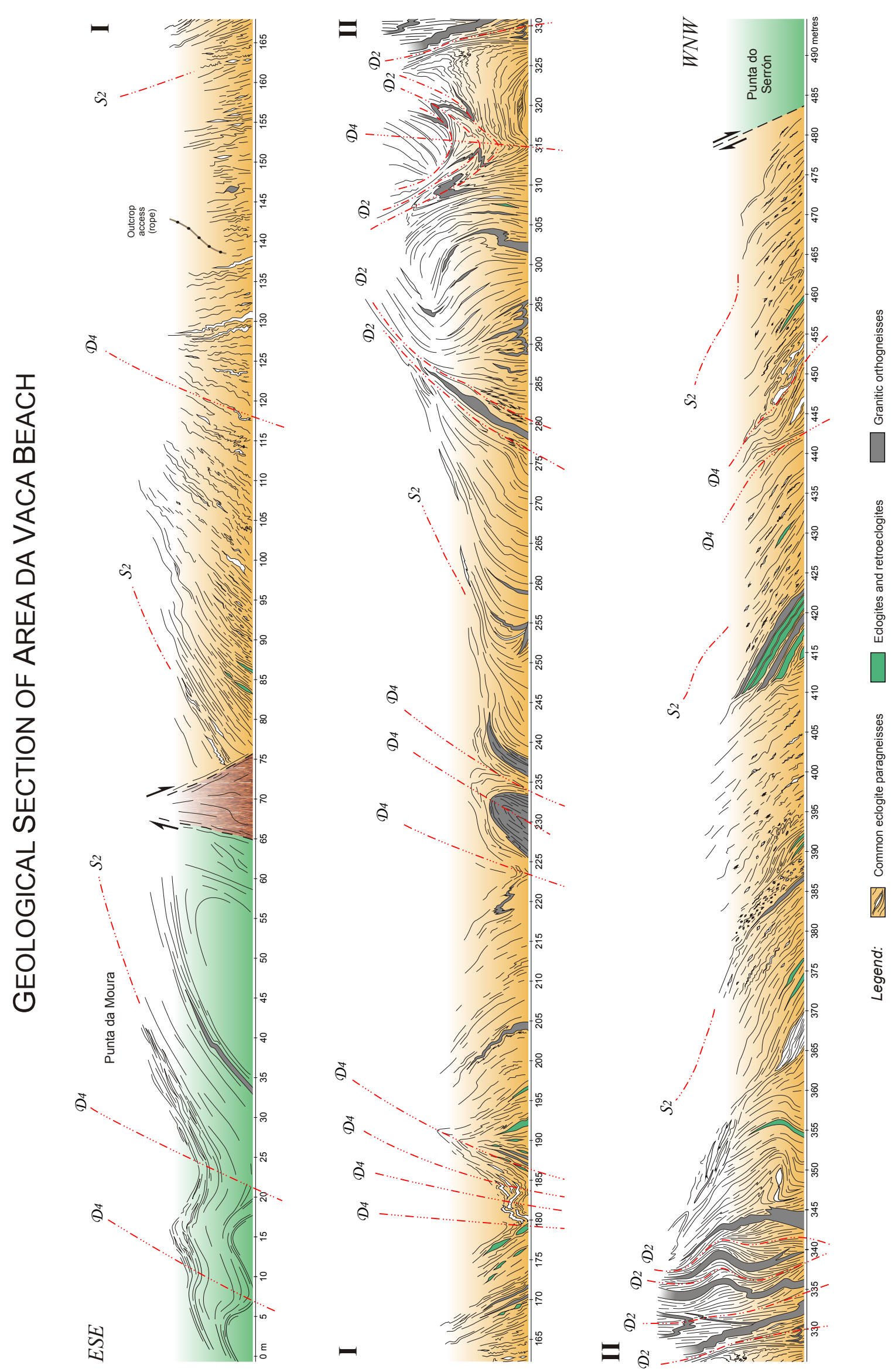

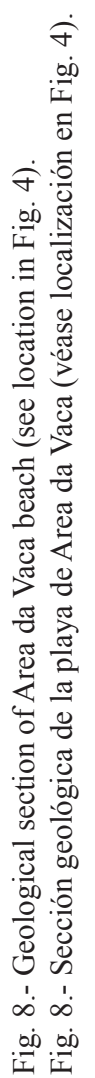


could be related, at least in the eastern part of the Cabo Ortegal Complex, the area that represents the front of the allochthonous complexes, the leading edge of the huge allochthonous pile moving to the East from the more internal zones of the orogen. The age of the thrust and the recumbent folds is not completely clear. The recumbent folds are younger than $390 \mathrm{Ma}$, which is a reference age for the migmatization and the development of the $\mathrm{S}_{2}$ foliation in the Cabo Ortegal Complex (Peucat et al., 1990; Fernández Suárez et al., 2007). On the other hand, these folds are also younger than the extensional contact between the Cariño Gneisses and the eclogitic gneisses, as this contact is folded by the large recumbent synform (Figs. 3 and 4). An extensional contact similar to this one and also affecting similar units in the Órdenes Complex was dated at $375 \mathrm{Ma}$ (Corredoiras detachments; Dallmeyer et al., 1997). The basal thrust of the upper units cuts the amphibolite facies foliation of the Purrido Unit (upper ophiolites), dated in the range of 391-377 Ma (Peucat et al., 1990; Dallmeyer et al., 1997). Moreover, the greenschist facies foliation of the Moeche Unit was dated at $364 \mathrm{Ma}$ (Dallmeyer et al., 1997). Therefore, the thrust and the associated recumbent folds are probably younger than $375 \mathrm{Ma}$, but older than $364 \mathrm{Ma}$.

The $S_{2}$ mylonitic foliation, the $D_{3}$ recumbent folds and the basal thrust are additionally affected by upright folds $\left(D_{4}\right)$, the largest of which is the huge open synform (klippen) of the Cabo Ortegal Complex (Fig. 3). Another important $\mathrm{D}_{4}$ fold is the smooth antiform centred in the Masanteo Peninsula (Fig. 4). Minor $\mathrm{D}_{4}$ folds are also abundant across the two sections represented in figures 7 and 8 . There is no axial planar foliation associated to $\mathrm{D}_{4}$ folds.

\section{Discussion: the exhumation of the HP-HT units}

The eclogite facies gneisses of the Cabo Ortegal Complex were subducted at a great depth. This is a gneiss formation similar to others described in the Variscan suture zone affected by ultra-high-P metamorphism. The P-T conditions obtained so far in this formation are less extreme than those considered characteristic for the UHP metamorphism, but relatively close (ca. $780-800{ }^{\circ} \mathrm{C}$ and $22 \mathrm{kbar}$ ). The eclogitic gneiss unit belongs to the upper units of the allochthonous complexes, a large crustal ensemble interpreted as a Cambrian peri-Gondwanan terrane with magmatic arc affinities. The high-P conditions that affected parts of this terrane indicate that they once constituted a subduction complex, developed on a continental or a transitional thinned continental margin containing thick sedimentary series. The deep subduc- tion ( $D_{1}$ event, see section 3.2) of this margin necessarily implies the existence of a prograde continent colliding with a retro-continent. Taking into account that the NW Iberian Variscan suture is rootless, which is also the situation of similar allochthonous terranes along the Variscan Belt (Fig. 1), and also considering that the upper allochthonous units are presently emplaced above ophiolites, it is not possible to obtain direct evidence about the identity of the involved continents. However, in the context of the gneissic unit and in present coordinates, subduction occurred with $10-30^{\circ} \mathrm{N}$ direction and top-to-the-North kinematics (Ábalos et al., 2011).

The subducted complex experienced a drastic and fast exhumation ( $\mathrm{D}_{2}$ event, see section 3.2) during generation of the decompressive mylonitic foliation $\left(\mathrm{S}_{2}\right)$ that constitutes the most prominent structural feature in the HPHT units. The magnitude of the exhumation registered during $\mathrm{D}_{2}$ can be calculated in ca. $10 \mathrm{kbar}$ and it was developed in ca. $10 \mathrm{Ma}$ (subduction at ca. 400-390 Ma vs. exhumation at ca. $390 \mathrm{Ma}$ ). Such a pronounced exhumation very likely occurred during continuous subduction of continental or transitional slices, i.e. new layers of the same terrane represented by the upper units that in a prograde accretionary sequence should be presently located below the HP-HT units (Platt, 1986). These units are not preserved, at least in NW Iberia, because the HPHT units rest above ophiolitic units, which avoid direct interpretation of the colliding margins. The progression of exhumation favors the generation of an important extensional detachment, which is represented by the contact between the Cariño Gneisses, in the amphibolite facies and located in the hanging wall, and the eclogite facies gneisses. Similar detachments have been also described in the Órdenes Complex, both inside the intermediate pressure units and also in the contact with the HP-HT units (Martínez Catalán et al., 2002). In that contact, the Corredoiras detachment shows almost identical characteristics to the detachment described above of the Banded Gneisses, with an age calculated at ca. $375 \mathrm{Ma}\left({ }^{40} \mathrm{Ar} /{ }^{39} \mathrm{Ar}\right.$ geochronology; Dallmeyer et al., 1997). The sketch shown in figure 9 presents a model for the exhumation of the eclogite facies gneisses and in general for the HP-HT units of the Cabo Ortegal Complex (paleogeographic reconstructions at these times have been published in many works, i.e. Gómez Barreiro et al., 2007).

The tectonothermal and exhumation history of the HPHT units, illustrated by the eclogite facies gneisses, fits quite well to the conclusions obtained by Beaumont et al. (2009) in relation to the exhumation of ultra-high-P complexes. Specifically the exhumation rates and the time range obtained for this process in the basis of ge- 
D2 EXHUMATION STAGE (ca. $390 \mathrm{Ma}$ )

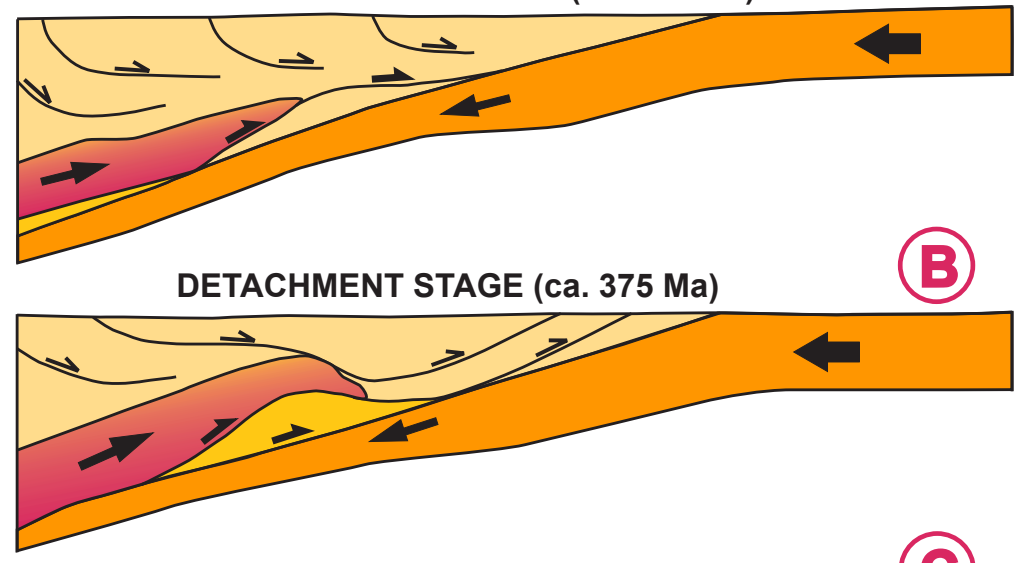

FOLD AND THRUST STAGE (ca. 375-364) Ma
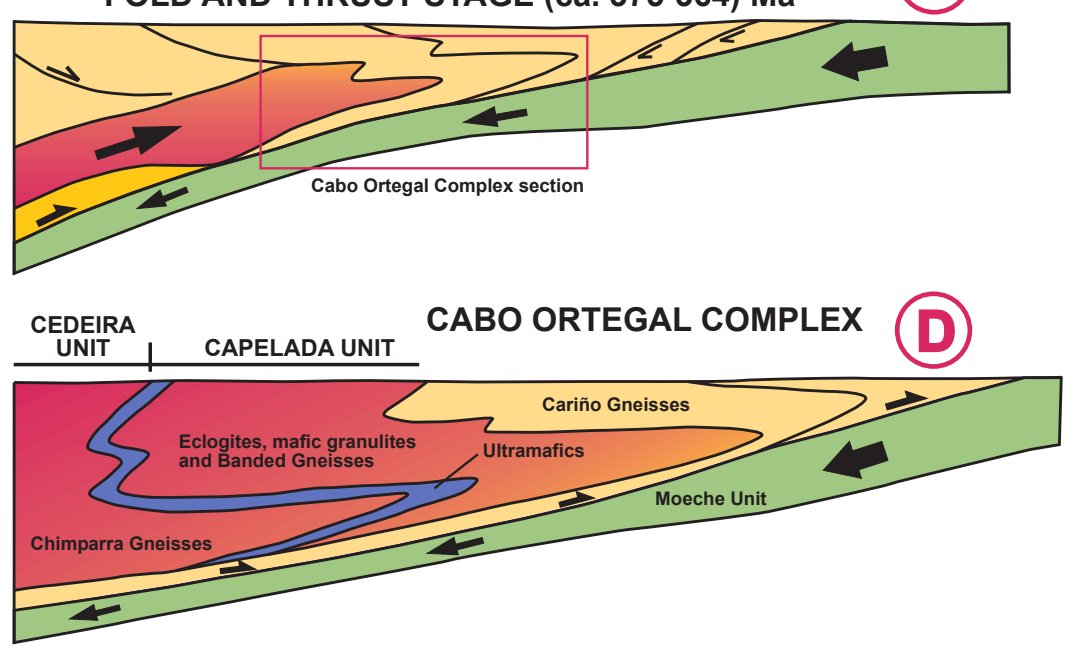

Fig. 9.- Sketches showing the tectonothermal evolution of the eclogite facies gneisses of the Cabo Ortegal Complex. Sections A-C represent progressive stages in exhumation during the development of the $\mathrm{S}_{2}$ regional mylonitic foliation (A), syn-convergence extensional detachments (B) and recumbent folds and thrusts (C). Sketch D shows an idealized section of the frontal eastern part of the Cabo Ortegal Complex.

Fig. 9.- Esquemas ilustrativos de la evolución tectonotermal de los gneises eclogíticos del Complejo de Cabo Ortegal. Las secciones A-C representan etapas progresivas de exhumación durante el desarrollo de la foliación regional milonítica $\mathrm{S}_{2}$ (A), despegues extensionales sincrónicos con la convergencia (B) y pliegues recumbentes y cabalgamientos (C). El esquema D muestra una sección idealizada de la parte frontal oriental del Complejo de Cabo Ortegal.

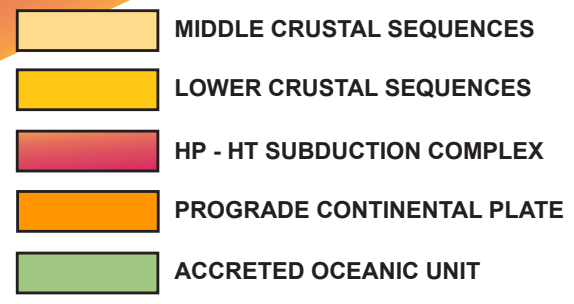

ochronological isotopic data, follows with significant detail the predictions based on numerical experiments. Moreover, as it has been discussed in previous sections, the progression of the deformational history in the upper units entails the development of large recumbent folds and a basal thrust $\left(\mathrm{D}_{3}\right.$ structures, see section 3.2 and figures 3 and 4). The geometry of both structures seems to indicate that their development could be related and that they represent the final events in the exhumation of the subducted complex. This is also in good agreement with the structural pattern predicted by the theoretical models (Warren et al., 2008; Beaumont et al., 2009), but in this case the time range, although uncertain, seems to be larger. Comparison of the structures predicted in these models and those explained in this paper are represented in figure 9, such as a UHP buoyant plume (HP-HT units) or large regional structures $\left(\mathrm{D}_{3}\right.$ recumbent folds and basal thrust). The progression of the exhumation entails an important change in the nature of the colliding plates, because during this evolution the prograde continental margin was replaced by the underthrusting of ophiolites (Fig.
9). These ophiolitic slices were initially accreted in amphibolite facies conditions (Purrido Unit), but they were finally replaced, after additional exhumation of the orogenic wedge, by the underthrusting of greenschist facies ophiolites (Moeche Unit). The paleogeographic meaning for this change in the type of subduction, from a continental subduction to the accretion of ophiolitic units, is presently uncertain, although it has been traditionally related to the closure of the Rheic Ocean (Gómez Barreiro et al., 2007; Sánchez Martínez et al., 2007).

The tectonothermal evolution of the eclogite facies gneisses of the Cabo Ortegal Complex represents an illustrative example of the complex history of these deeply subducted complexes, which are relatively frequent in the suture zone of the Variscan Belt. It is important to remark that the structural, metamorphic and geochronological patterns in the evolution of this gneissic unit follows almost perfectly the predictions based in numerical experiments about the exhumation of ultra-high-P complexes. Consequently, it represents a direct confirmation of the reality of these models. 


\section{Acknowledgements}

Financial support for this research has been provided by the Spanish project CGL2007-65338-CO2-01/BTE (Ministerio de Economía y Competitividad). Insightful review of the manuscript performed by Jean-Marc Lardeaux and Francisco Martínez are gratefully acknowledged, as well as the editorial work and suggestions of Cesar Casquet. Richard Albert thanks to the Universidad Complutense de Madrid which provided him with a fouryear pre-doctoral grant. This study is also a contribution to the IGCP 597 project, Amalgamation and breakup of Pangaea: the type example of the supercontinent cycle.

\section{References}

Ábalos, B., Puelles, P., Gil Ibarguchi, J.I. (2003): Structural assemblages of high-pressure mantle and crustal rocks in a subduction channel (Cabo Ortegal, NW Spain). Tectonics 22, 1-21. doi: 10.1029/2002tc001405.

Ábalos, B., Fountain, D.M., Gil Ibarguchi, J.I., Puelles, P. (2011): Eclogite as a seismic marker in subduction channels: Seismic velocities, anisotropy, and petrofabric of Cabo Ortegal eclogite tectonites (Spain). Geological Society of America Bulletin 123, 439-456. doi: 10.1130/b30226.1.

Abati, J., Dunning, G.R., Arenas, R., Díaz García, F., González Cuadra, P., Martínez Catalán, J.R., Andonaegui, P. (1999): Early Ordovician orogenic event in Galicia (NW Spain): evidence from $\mathrm{U}-\mathrm{Pb}$ ages in the uppermost unit of the Ordenes Complex. Earth and Planetary Science Letters 165, 213-228. doi: 10.1016/s0012$821 x(98) 00268-4$.

Abati, J., Castiñeiras, P., Arenas, R., Fernández-Suárez, J., Gómez Barreiro, J., Wooden, J. (2007): Using SHRIMP-RG U-Pb zircon dating to unravel tectonomagmatic events in arc environments. The early Paleozoic arc of NW Iberia revisited. Terra Nova 19, 432-439. doi: 10.1111/j.1365-3121.2007.00768.x.

Abati, J., Gerdes, A., Fernández-Suárez, J., Arenas, R., Whitehouse, M.J., Díez Fernández, R. (2010): Magmatism and early-Variscan continental subduction in the northern Gondwana margin recorded in zircons from the basal units of Galicia, NW Spain. Geological Society of America Bulletin 122, 219-235. doi: 10.1130/b26572.1.

Allemand, P., Lardeaux, J.M. (1997): Strain partitioning and metamorphism in a deformable orogenic wedge: Application to the Alpine belt. Tectonophysics 280, 157-169. doi: 10.1016/S00401951(97)00136-4.

Arenas, R., Gil Ibarguchi, J.I., González Lodeiro, F., Klein, E., Martínez Catalán, J.R., Ortega Gironés, E., Pablo Maciá, J.G. de, Peinado, M. (1986): Tectonostratigraphic units in the complexes with mafic and related rocks of the NW of the Iberian Massif. Hercynica II, 87-110.

Arenas, R., Rubio Pascual, F.J., Díaz García, F., Martínez Catalán, J.R. (1995): High-pressure micro-inclusions and development of an inverted metamorphic gradient in the Santiago Schists (Ordenes Complex, NW Iberian Massif, Spain): evidence of subduction and syn-collisional decompression. Journal of Metamorphic Geology 13, 141-164. doi: 10.1111/j.1525-1314.1995.tb00211.x.

Arenas, R., Martínez Catalán, J.R. (2002): Prograde development of corona textures in metagabbros of the Sobrado unit (Órdenes
Complex, northwestern Iberian Massif). In: Martínez Catalán, J.R., Hatcher, R.D., Jr, Arenas, R. and Díaz García, F. (eds.), VariscanAppalachian dynamics: The building of the late Paleozoic basement. Geological Society of America, Special Paper 364: 73-88. doi:10.1130/0-8137-2364-7.73.

Arenas, R., Martínez Catalán, J.R., Sánchez Martínez, S., FernándezSuárez, J., Andonaegui, P., Pearce, J.A., Corfu, F. (2007): The Vila de Cruces Ophiolite: A remnant of the early Rheic Ocean in the Variscan suture of Galicia (NW Iberian Massif). Journal of Geology 115, 129-148. doi: 10.1086/510645.

Arenas, R., Sánchez Martínez, S., Castiñeiras, P., Jeffries, T.E., Díez Fernández, R., Andonaegui, P. (2009): The basal tectonic mélange of the Cabo Ortegal Complex (NW Iberian Massif): a key unit in the suture of Pangea. Journal of Iberian Geology 35, 85-125.

Beaumont, C., Jamieson, R.A., Butler, J.P., Warren, C.J. (2009): Crustal structure: A key constraint on the mechanism of ultra-highpressure rock exhumation. Earth and Planetary Science Letters 287, 116-129. doi: 10.1016/j.eps1.2009.08.001.

Castiñeiras, P. (2005): Origen y evolución tectonotermal de las unidades de O Pino y Cariño (Complejos Alóctonos de Galicia). Nova Terra 28: $279 \mathrm{p}$.

Chopin, C. (2003): Ultrahigh-pressure metamorphism; tracing continental crust into the mantle. Earth and Planetary Science Letters 212, 1-14. doi: 10.1016/s0012-821x(03)00261-9.

Dallmeyer, R.D., Martínez Catalán, J.R., Arenas, R., Gil Ibarguchi, J.I., Guiérrez Alonso, G., Farias, P., Bastida, F., Aller, J. (1997): Diachronous Variscan tectonothermal activity in the NW Iberian Massif: Evidence from ${ }^{40} \mathrm{Ar} /{ }^{39} \mathrm{Ar}$ dating of regional fabrics. Tectonophysics 277, 307-337. doi: 10.1016/s0040-1951(97)00035-8.

Díaz García, F., Arenas, R., Martínez Catalán, J.R., González del Tánago, J., Dunning, G. (1999): Tectonic evolution of the Careón ophiolite (Northwest Spain): a remnant of oceanic lithosphere in the Variscan belt. Journal of Geology 107, 587-605.

Díaz García, F., Sánchez Martínez, S., Castiñeiras, P., Fuenlabrada, J.M., Arenas, R. (2010): A peri-Gondwanan arc in NW Iberia. II: Assessment of the intra-arc tectonothermal evolution through U-Pb SHRIMP dating of mafic dykes. Gondwana Research 17, 352-362. doi: 10.1016/j.gr.2009.09.010.

Díez Fernández, R., Martínez Catalán, J.R., Arenas, R., Abati, J. (2011): Tectonic evolution of a continental subduction-exhumation channel: Variscan structure of the basal allochthonous units in NW Spain. Tectonics 30. doi: 10.1029/2010TC002850.

Fernández Suárez, J., Corfu, F., Arenas, R., Marcos, A., Martínez Catalán, J.R., Díaz García, F., Abati, J., Fernández, F.J. (2002): U-Pb evidence for a polyorogenic evolution of the HP-HT units of the NW Iberian Massif. Contributions to Mineralogy and Petrology 143, 236-253. doi: 10.1007/s00410-001-0337-2.

Fernández-Suárez, J., Arenas, R., Abati, J., Martínez Catalán, J.R., Whitehouse, M.J., Jeffries, T.E. (2007): U-Pb chronometry of polymetamorphic high-pressure granulites: An example from the allochthonous terranes of the NW Iberian Variscan belt. In: Hatcher, R.D., Jr., Carlson, M.P., McBride, J.H. and Martínez Catalán, J.R. (eds.), 4-D framework of continental crust. Geological Society of America, Memoir 200: 469-488. doi: 10.1130/2007.1200(24).

Fuenlabrada, J.M., Arenas, R., Sánchez Martínez, S., Díaz García, F., Castiñeiras, P. (2010): A peri-Gondwanan arc in NW Iberia. I: Isotopic and geochemical constraints on the origin of the arc - A sedimentary approach. Gondwana Research 17, 338-351. doi: 10.1016/j.gr.2009.09.007.

Gerya, T.V., Stöckhert, B., Perchuk, A.L. (2002): Exhumation of highpressure metamorphic rocks in a subduction channel: A numerical 
simulation. Tectonics 21, 6-1-19. doi: 10.1029/2002tc001406.

Gerya, T., Stöckhert, B. (2006): Two-dimensional numerical modeling of tectonic and metamorphic histories at active continental margins. International Journal of Earth Sciences 95, 250-274. doi: 10.1007/ s00531-005-0035-9.

Gil Ibarguchi, J.I., Mendia, M., Girardeau, J., Peucat, J.J. (1990): Petrology of eclogites and clynopiroxene-garnet metabasites from the Cabo Ortegal Complex (northwestern Spain). Lithos 25, 133-162. doi: 10.1016/0024-4937(90)90011-O.

Girardeau, J., Gil Ibarguchi, J.I., Ben Jamaa, N. (1989): Evidence for heterogeneous upper mantle in the Cabo Ortegal Complex, Spain. Science 245, 1231-1233. doi: 10.1126/science.245.4923.1231.

Gómez Barreiro, J., Martínez Catalán, J.R., Arenas, R., Castiñeiras, P., Abati, J., Díaz García, F., Wijbrans, J.R. (2007): Tectonic evolution of the upper allochthon of the Órdenes complex (northwestern Iberian Massif): Structural constraints to a polyorogenic periGondwanan terrane, in: Linneman, U., Nance, R.D., Kraft, P. and Zulauf, G. (eds.), The evolution of the Rheic Ocean: From Avalonian-Cadomian active margin to Alleghenian-Variscan collision. Geological Society of America, Special Paper 423: 315-332. doi: 10.1130/2007.2423(15).

Kretz, R. (1983): Symbols for rock-forming minerals. American Mineralogist $68,277-279$.

Kryza, R., Pin, C. (2002): Mafic rocks in a deep-crustal segment of the Variscides (the Góry Sowie, SW Poland): evidence for crustal contamination in an extensional setting. International Journal of Earth Science 91, 1017-1029. doi: 10.1007/s00531-002-0294-7.

Lardeaux, J.M., Ledru, P., Daniel, I., Duchene, S. (2001): The Variscan French Massif Central-a new addition to the ultra-high pressure metamorphic 'club': exhumation processes and geodynamic consequences. Tectonophysics 332, 143-167. doi: 10.1016/s00401951(00)00253-5.

Marcos, A., Marquínez, J., Pérez-Estaún, A., Pulgar, J.A., Bastida, F. (1984): Nuevas aportaciones al conocimiento de la evolución tectonometamórfica del Complejo de Cabo Ortegal (NW de España). Cuadernos do Laboratorio Xeolóxico de Laxe 7, 125-137.

Martínez Catalán, J.R., Arenas, R., Díaz García, F., Rubio Pascual, F.J., Abati, J., Marquínez, J. (1996): Variscan exhumation of a subducted Paleozoic continental margin: The basal units of the Ordenes Complex, Galicia, NW Spain. Tectonics 15, 106-121. doi: 10.1029/95tc02617.

Martínez Catalán, J.R., Díaz García, F., Arenas, R., Abati, J., Castiñeiras, P., González Cuadra, P., Gómez Barreiro, J., Rubio Pascual, F. (2002): Thrust and detachment systems in the Ordenes Complex (northwestern Spain): Implications for the Variscan-Appalachian geodynamics, in: Martínez Catalán, J.R., Hatcher, R.D., Jr, Arenas, R. and Díaz García, F. (Eds.), Variscan-Appalachian dynamics: The building of the late Paleozoic basement. Geological Society of America, Special Paper 364: 163-182. doi:10.1130/0-8137-2364-7.163.

Martínez Catalán, J.R., Arenas, R., Abati, J., Sánchez Martínez, S., Díaz García, F., Fernández Suárez, J., González Cuadra, P., Castiñeiras, P., Gómez Barreiro, J., Díez Montes, A., González Clavijo, E., Rubio Pascual, F.J., Andonaegui, P., Jeffries, T.E., Alcock, J.E., Díez Fernández, R., López Carmona, A. (2009): A rootless suture and the loss of the roots of a mountain chain: The Variscan belt of NW Iberia. Comptes Rendus Geoscience 341, 114-126. doi: 10.1016/j.crte.2008.11.004.Massonne, H.-J. (2001): First find of coesite in the ultrahigh-pressure metamorphic area of the central Erzgebirge, Germany. European Journal of Mineralogy 13, 565570. doi: 10.1127/0935-1221/2001/0013-0565.

Massone, H.-J. (2003): A comparison of the evolution of diamondifer- ous quartz-rich rocks from the Saxonian Erzgebirge and the Kokchetav Massif: Are so-called diamondiferous gneisses magmatic rocks? Earth and Planetary Science Letters 216, 347-364. doi: 10.1016/s0012-821x(03)00512-0.

Massone, H.-J., Kennedy, A., Nasdala, L., Theye, T. (2007): Dating of zircon and monazite from diamondiferous quartzofeldspathic rocks of the Saxonian Erzgebirge - hints at burial and exhumation velocities. Mineralogical Magazine 71, 407-425. doi: 10.1180/minmag.2007.071.4.407.

Mendia, M.S. (2000): Petrología de la Unidad Eclogítica del Complejo de Cabo Ortegal (NW de España). Nova Terra 16: 424 p.

Obrien, P.J., Vrana, S. (1995): Eclogites with a short-lived granulite facies overprint in the Moldanubian Zone, Czech Republic: petrology, geochemistry and diffusion modelling of garnet zoning. Geologische Rundschau 84, 473-488. doi: 10.1007/s005310050019.

Ordóñez Casado, B., Gebauer, D., Schäfer, H.J., Gil Ibarguchi, J.I., Peucat, J.J. (2001): A single Devonian subduction event for the HP/ HT metamorphism of the Cabo Ortegal complex within the Iberian Massif. Tectonophysics 332, 359-385. doi: 10.1016/S00401951(00)00210-9.

Peucat, J.J., Bernard-Griffiths, J., Gil Ibarguchi, J.I., Dallmeyer, R.D., Menot, R.P., Cornichet, J., Iglesias Ponce de León, M., (1990): Geochemical and geochronological cross section of the deep Variscan crust: The Cabo Ortegal high-pressure nappe (northwestern Spain). Tectonophysics 177, 263-292. doi: 10.1016/0040-1951(90)90285-g.

Platt, J.P. (1986): Dynamics of orogenic wedges and the uplift of highpressure metamorphic rocks. Geological Society of America Bulletin 97, 1037-1053. doi: 10.1130/0016-7606(1986)97<1037:DOO WAT $>2.0 . \mathrm{CO} ; 2$.

Platt, J.P. (1993): Exhumation of high pressure rocks: a review of concepts and processes. Terra Nova 5, 119-133. doi: 10.1111/j.13653121.1993.tb00237.x.

Puelles, P., Ábalos, B., Gil Ibarguchi, J.I. (2009): Transposed highpressure granulite fabrics (Cabo Ortegal, NW Spain): implications on the scales of deformation localization. Journal of Structural Geology 31, 776-790. doi: 10.1016/j.jsg.2009.05.001.

Sánchez Martínez, S., Arenas, R., Díaz García, F., Martínez Catalán, J.R., Gómez-Barreiro, J., Pearce, J.A. (2007): Careón Ophiolite, NW Spain: Supra-subduction zone setting for the youngest Rheic ocean floor. Geology 35, 53-56. doi: 10.1130/g23024a.1.

Sánchez Martínez, S., Arenas, R., Gerdes, A., Castiñeiras, P., Potrel, A., Fernández-Suárez, J. (2011): Isotope geochemistry and revised geochronology of the Purrido Ophiolite (Cabo Ortegal Complex, NW Iberian Massif): Devonian magmatism with mixed sources and involved Mesoproterozoic basement. Journal of the Geological Society, London 168, 733-750. doi: 10.1144/0016-76492010-065.

Santos Zalduegui, J.F., Schärer, U., Gil Ibarguchi, J.I., Girardeau, J. (1996): Origin and evolution of the Paleozoic Cabo Ortegal ultramafic-mafic complex (NW Spain): U-Pb, $\mathrm{Rb}-\mathrm{Sr}$ and $\mathrm{Pb}-\mathrm{Pb}$ isotope data. Chemical Geology 129, 281-304. doi: 10.1016/00092541(95)00144-1.

Simancas, J.F., Tahiri, A., Azor, A., González Lodeiro, F., Martínez Poyatos, D.J., El Hadi, H. (2005): The tectonic frame of the Variscan-Alleghanian orogen in Southern Europe and Northern Africa. Tectonophysics 398, 181-198. doi: 10.1016/j.tecto.2005.02.006.

Timmermann, H., Štědrá, V., Gerdes, A., Noble, S.R., Parrish, R.R., Dörr, W. (2004): The problem of dating high-pressure metamorphism: a U-Pb isotope and geochemical study on eclogites and related rocks of the Mariánské Lázně Complex, Czech Republic. Journal of Petrology 45, 1311-1338. doi: 10.1093/petrology/ egh020. 
Vogel, D.E. (1967): Petrology of an eclogite- and pyrigarnite-bearing polymetamorphic rock complex at Cabo Ortegal, NW Spain. Leidse Geologische Mededelingen 40, 121-213.

Warren, C.J., Beaumont, C., Jamieson, R.A. (2008): Modelling tectonic styles and ultra-high pressure (UHP) rock exhumation during the transition from oceanic subduction to continental collision.
Earth and Planetary Science Letters 267, 129-145. doi: 10.1016/j. eps1.2007.11.025.

Yamato, P., Burov, E., Agard, P., Le Pourhiet, L., Jolivet, L. (2008): HP-UHP exhumation during slow continental subduction: Self-consistent thermodynamically and thermomechanically coupled model with application to the Western Alps. Earth and Planetary Science Letters 271, 63-74. doi:10.1016/j.eps1.2008.03.049. 